Published in Social Science Research 52:659-670.

https://www.sciencedirect.com/science/article/pii/S0049089X14001926

\title{
Small Groups, Contexts, and Civic Engagement: A Multilevel Analysis of United States Congregational Life Survey Data*
}

\author{
Andrew L. Whitehead \\ Department of Sociology \& Anthropology \\ Clemson University \\ Samuel Stroope \\ Department of Sociology \\ Louisiana State University
}

\begin{abstract}
*The authors would like to thank the editor and anonymous reviewers for their helpful comments. Correspondence should be addressed to Andrew L. Whitehead, Department of Sociology \& Anthropology, Clemson University, 132 Brackett Hall, Clemson, SC 29634. Email: alw6@clemson.edu. A portion of this research was presented at the 2011 Society for the Scientific Study of Religion annual meetings and was supported by the Henry Institute at Calvin College.
\end{abstract}




\title{
Small Groups, Contexts, and Civic Engagement: A Multilevel Analysis of United States Congregational Life Survey Data
}

\begin{abstract}
Prior research suggests that church-goers are more civically engaged than their non-church-going counterparts. Little is known, however, about how the popular phenomenon of small groups factors into this equation. In the present study, we examine relationships between small group participation at individual and congregation levels and civic engagement. Using multilevel modeling and national data on congregations and individuals from the U.S. Congregational Life Study ( $n=82,044)$, we find that: (1) individual-level small group involvement is associated with four measures of civic engagement; (2) congregation-level small group participation is associated with both lower and higher civic engagement in the case of two outcomes; and (3) in the case of three civic outcomes, congregation-level small group participation moderates individual-level small group involvement such that small group members' civic activity more closely resembles the lower civic engagement of small group nonparticipants. In the case of one civic outcome, at high levels of overall small group participation, small group members' civic engagement drops below that of small group nonparticipants. Explanations for these findings, including a "crowding out" effect, are examined including their complex implications for debates regarding small groups, religious involvement, and civic engagement.
\end{abstract}

Keywords: civic engagement, community, small groups, crowding out, congregations, HLM, social networks, organizations, church, religion, United States 
In Sharing the Journey, Wuthnow (1994b) argues that a new organizational form is sweeping across America—small groups. For Wuthnow, small groups seek to fill the void of social interaction and a sense of belonging that are evaporating amid the loss of community in America. Wuthnow suggests that small groups can "nudge" individuals "to play an active role in voluntary agencies," and become civically engaged in service of the wider community (Wuthnow 1994b: 330). In other words, small groups may do more than comfort the individual; small groups may also be an emerging engine of civic engagement.

Not everyone agrees. Scholars do not necessarily dispute the social and psychological benefits to individual small group members, but argue that small groups may not necessarily benefit the broader community (Putnam 2000). Small groups can leave members in a social culde-sac, insulating them from more expanded social network contacts in the community or "bridging social capital," the lack of which can have a variety of negative effects (Lee and Bartkowski 2004; Tolbert, Lyson, and Irwin 1998). Inwardly-focused small groups bound individuals' social networks resulting in decreased engagement with broader civic opportunities and concerns, a "crowding out" effect due to increased opportunity costs (Frey 1997a, 1997b; Menchik and Weisbrod 1987). Recent analyses of Wuthnow's data show that some religious small groups are linked to lower levels of civic engagement (Marcello and Perrucci 2009). This association is somewhat puzzling given the robust links between individuals' church involvement and civic engagement in the United States (Putnam 2000; Putnam and Campbell 2012) and cross-nationally (Ruiter and De Graaf 2006).

More research is needed to understand the relationship between congregation-based small group participation and civic engagement beyond the congregation. These issues are of broad concern given that religious congregations enjoy the highest levels of involvement among 
voluntary organizations in the United States (Putnam and Campbell 2010:29-30) and a majority of the nation's largest congregations use small groups (Bird and Thumma 2011).

Within this line of inquiry, recent studies highlight the role of religious contextual effects on civic engagement. A growing body of research examines the importance of religious contexts in civic engagement across national, local, and social network contexts (Borgonovi 2008; Lim and MacGregor 2012; Lewis, MacGregor, and Putnam 2012, Ruiter and De Graaf 2006). Recent research on commitment and voluntary behavior within religious congregations measures religious contextual effects at the organization level (Scheitle and Finke 2008; Stroope 2011a; Whitehead 2010). In this literature, Whitehead (2010) finds that overall small group participation at the congregation level moderates the effects of individuals' religious characteristics on financial giving. Given this background, overall small group participation may also play a role in other forms of voluntary behavior and community engagement. The importance of congregational overall small group participation regarding the relationship between small groups and community civic engagement, however, remains unstudied.

To shed light on this gap in the literature on small groups, religion, and civic engagement, we develop and test three hypotheses concerning relationships between individual civic engagement and small group participation at the individual level, organization level, and their cross-level interplay. Four measures of civic engagement are examined in national data on 408 congregations and 83,564 members from the 2001 U. S. Congregational Life Survey using multilevel modeling techniques. Employing a multilevel "moral communities" framework and insights from organizational science, this study builds on prior contextual effects, religion, and civic engagement literature. Prior work is limited in that it (a) measures volunteering and commitment within religious congregations rather than volunteering for the community or civic 
engagement beyond the congregation, (b) focuses on general religious small groups instead of small groups in congregations, (c) measures the contextual effects of religion using geographic rather than organizational contexts, (d) uses data on individual measures or congregational measures but not measures at both levels simultaneously, and (e) does not use national samples of churches and individuals nested in those churches.

\section{Religion and Civic Engagement}

According to a growing body of research based on numerous data sets gathered across a variety of contexts and times, religious individuals are more civically engaged than nonreligious individuals (Lam 2002; Putnam and Campbell 2010). Important aspects of religious life, such as church attendance, are repeatedly found to be associated with civic engagement (Lam 2002; Putnam 2000; Schwadel 2005; Wuthnow 1996). Members of religious congregations volunteer more hours and more frequently than non-members and give away more money to both religious and secular causes (Putnam 2000; Smidt et al. 2008). Frequency of religious behavior matters as well. Higher levels of attendance at religious worship services are associated with higher levels of volunteering and charitable giving (Brooks 2003; Campbell and Yonish 2003). While the relationship between religiosity and religious volunteering is clear, there is considerable evidence that religion also encourages greater levels of civic engagement through both volunteering in and charitable giving to nonreligious voluntary organizations (Brooks 2003; Campbell and Yonish 2003; Ruiter and De Graaf 2006).

Two mechanisms are routinely cited to help explain the connection between religion and civic engagement. First, scholars argue that there is something important about religion itself that motivates individuals to be civically engaged (Lam 2002; Loveland et al. 2005). Many faiths teach that adherents should care for fellow human beings. Belief in such religious teachings 
could lead individuals to volunteer or give of their resources (Ellison 1992; Wuthnow 1990). Private prayer and frequent reading of sacred scriptures are associated with greater levels of civic engagement (Lam 2002; Loveland et al. 2005). Individuals who pair high levels of personal religious activity with high levels of public religious activity are especially likely to be civically engaged with both religious and secular organizations (Smidt et al. 2008).

A second mechanism used to explicate the relationship between religion and civic engagement is the power of social networks. The reason that religious individuals give and volunteer more than the non-religious is because religious individuals are connected to more people and those connections matter (Becker and Dhingra 2001). It is the social networks religion encourages, and not anything about religion per se, that explain the relationship between civic engagement and religion (Putnam 2000). This happens in several ways. Congregations operate as recruiting centers where people can be readily recruited for service (Wuthnow 1991, 1994b). Congregations and religious activities can also highlight needs in the community to people who otherwise might not been made aware of such needs. The social networks explanation is especially persuasive considering that the effects of frequency of attendance are identical for those who attend secular groups (Campbell and Yonish 2003). Individuals who consistently attend any group's meetings, no matter if the group is religious or secular, exhibit higher levels of civic engagement. Also, more associational memberships translate into greater levels of engagement (Smidt et al. 2008). Therefore, the recruiting and need-sharing effects of strong social networks operate across different types of networks. It is worth noting, however, that the bulk of associational memberships in the United States are religious (Smidt et al. 2008).

\section{Small Groups, Congregations, and Civic Engagement}


Research that highlights the power of social networks, especially regarding religion, often points to the importance of small groups for strengthening networks (Beyerlein and Hipp 2006; Scheitle and Finke 2008; Stark and Finke 2000; Wuthnow 1994a, 1994b). The growing prevalence of small groups is seen both in American religion and in other arenas of life (Wuthnow 1994a, 1994b). Through the 1990s and the first decade of the twenty-first century, small groups proliferated throughout the United States. These groups were most often religious in their focus, but many organized around common interests or goals such as sports or community development (Wuthnow 1994b). The small group revolution prompted many popular commentators to encourage the use of small groups within congregations to encourage dynamic growth. Many congregations, especially megachurches, implemented a small group structure (Thumma and Travis 2007).

While many congregations institute small groups for internal benefits, prior research demonstrates that involvement in small groups promotes civic engagement for a variety of reasons. First, involvement in small groups serves to integrate congregants more deeply into the congregation and promote higher levels of giving, attendance, and encourage a sense of belonging (Dougherty and Whitehead 2011; Whitehead 2010). Close connection to a religious community is important because it produces higher levels of civic engagement even after adjusting for the influence of religious belief (Wuthnow 1991). This happens because small group involvement ties individuals to congregations such that other civic engagement-enhancing influences of the congregation become effectual (e.g., hearing and responding to volunteer invitations from the pulpit).

Second, through small groups, individuals are alerted to needs both within the congregation as well as in the wider community (Wuthnow 1994b). Individuals in small groups 
receive face-to-face information from lay small group leaders and members-people they know and likely trust on a personal level—regarding ways in which they can volunteer, perhaps alongside their fellow small group members. In fact, some congregations encourage each individual small group to coordinate volunteering as a group by adopting a community project (e.g., cleanup at a local school).

Third, small groups serve as accountability groups where individuals are expected to serve in some way (Thumma and Travis 2007; Wuthnow 1994b). Scholars argue that social rewards and punishments play a strong role in religious behavior and belief (Stroope 2012). Norms of community service and the related group social sanctions provide powerful incentive for ongoing volunteering.

Fourth, small groups serve as training grounds for civic skills and engagement behavior. In small groups, individuals are often provided abundant opportunities to practice administrative, communication, and leadership skills on a small scale. Such skills are readily translatable to a variety of civic engagement activities beyond the congregation (Verba, Schlozman, and Brady 1995).

Finally, small group participation is encouraged by many congregations because these groups can serve to strengthen and deepen the religious faith of participants (Clemmons and Hester 1974). Religious beliefs such as compassion for the poor and scriptural injunctions to love one's neighbor, apart from social network effects, serve to cultivate altruistic dispositions and encourage greater levels of civic engagement (Wuthnow 1990). Thus, small groups are generally believed to have "an overall positive effect on involvement in wider community activities" (Wuthnow 1994b: 330). Individuals become more involved and greater levels of involvement translate into more civic engagement (Brooks 2003; Campbell and Yonish 2003). Therefore, 
given our focus on testing the organizational effects of small group participation, we first replicate past literature and control for the effect of small group participation at the individual level $^{1}$ :

Hypothesis 1: Net of other individual-level and congregation-level factors, involvement in a small group at the individual level will be positively associated with civic engagement.

The positive effects of small group involvement on civic engagement may also be present at the congregation level. Regarding financial giving, research demonstrates that religious congregations with more individuals involved in small groups have higher average levels of financial donations to the congregation, net of individual and congregation-level characteristics (Whitehead 2010). Additionally, these congregations create a context within which individuallevel determinants of giving (e.g., individual service attendance and individual beliefs) become more robust. Similarly, congregations that involve a greater proportion of congregants in small groups may create a context within which civic engagement is more likely.

These congregational contexts can also result in bolstering individual-level inputs to civic engagement. The effects operate because the mechanisms present in each small group aggregate to the congregation as a whole. Accounting for aggregate levels of small group involvement at the congregational level also taps a congregation's ability to self-structure. By accounting for each congregation's overall level of small group involvement, we can view the congregation as not merely an aggregate of all its parts (Whitehead 2010). Many congregations intentionally work to involve congregants in a small group to increase social network density, member

\footnotetext{
${ }^{1}$ In a series of ancillary models (not shown), we entered variables that we identified as measures of the mechanisms by which small group participation affects civic engagement: (1) integration (sense of belonging), (2) need awareness (value for congregation's community care/social justice emphasis), (3) accountability (no measure identified), (4) civic skills (congregational roles), or (5) faith commitment (growth in faith). Several of these variables were significant in most, but not all, models. In all cases, however, any variations in the effects of small group were modest. We caution that the above measures may not be adequate measures of these concepts, which other datasets could better address.
} 
retention, organizational participation, and adherence to beliefs and behaviors encouraged by the congregation - they self-structure (Thumma and Travis 2007). Congregations with more individuals involved in small groups benefit from a context of more dense social networks, greater levels of accountability, more efficient need-sharing, and religious adherence (Thumma and Travis 2007; Whitehead 2010; Wuthnow 1994b). These arguments lead to the following hypothesis:

Hypothesis 2: Net of other individual-level and congregation-level factors, as the proportion of individuals in a congregation who are involved in small groups increases, the probability of civic engagement will increase.

Theorizing forwarded by organizational researchers argues that a person's ability to absorb from his or her social context is an important factor in how a social context will influence a person's behavior. The influence of context depends on one's capacity to absorb from that context - a number of people "may be able to access knowledge through [their] network links but [others] may not have sufficient capacity to absorb such knowledge', (Tsai 2001: 1003). A congregant involved in a small group should have greater capacity to be affected by a small group-dominated congregational context. This capacity to be affected amplifies congregationlevel influences on civic engagement (e.g. through networks, need-sharing, skills, and religious beliefs and behaviors).

The foregoing argument is consistent with a parallel literature on religious geographic and school contexts which examines whether religious beliefs affect behavior only when surrounded by a "moral community" of co-religionists (Bjarnason et al. 2005; Lee and Bartkowski 2004; Wallace et al. 2007). Applied to the present analysis, if overall congregational small group structure maintains an environment encouraging service to others, this context can 
ratify beliefs and behaviors of service fostered at the level of individual small group

participation. Existing research on congregations is consistent with this view, showing that congregation-level educational attainment increases the effects of individual education on religious belief (Stroope 2011b). In this way, social context changes the balance between potentially competing ideologies, with the possibility that one ideology or set of actions will win. The values, orientations, tastes, and proficiencies cultivated in small groups that motivate or bolster civic engagement are encouraged in the context of people also encouraged toward civic engagement in the same ways. Therefore, a person in a small group discussing the practical applications of Jesus' teaching to love one's neighbor and serve the poor are more likely to translate that teaching into action when among fellow congregants immersed in related discussions. This study's third hypothesis follows:

Hypothesis 3: Net of other individual-level and congregation-level factors, the proportion of congregants involved in a small group will amplify the positive relationship between individual-level small group involvement and civic engagement.

Despite the increased popularity of small groups and their potentially beneficial qualities, many questions remain regarding whether small group involvement is entirely beneficial and who does or does not benefit. Wuthnow (1994a, 1994b) pointed to the tendency of small groups to turn inward and begin to focus only on personal growth and development. Further analysis on the data used in Wuthnow's study suggests that strictly religious small group participants are less likely to engage in civic activities compared to secular or mixed group participants (groups that are both religious and secular) (Marcello and Perrucci 2009). In fact, some scholars point to heightened density of intra-group social networks as detrimental to civic engagement (Fiorina 1999; Putnam 2000; Scheitle and Adamczyk 2009; Schwadel 2005). Such groups are self- 
focused to such an extent that the world outside the group is neglected. Prior research on voluntary behavior suggests this is due to a "crowding out" effect. ${ }^{2}$ The increased opportunity costs of participating in civic activities, above and beyond the time and energy investments given to participating in a small group, "crowd out" the propensity of individuals to do engage civically (Frey 1997a, 1997b; Frey and Götte 1999; Menchik and Weisbrod 1987).

Dense networks can limit the interaction individuals have with people outside the small group. The bonding capital encouraged by small groups overshadows or constrains the bridging capital needed to successfully engage in wider civic concerns. Small group participation "crowds out" participation in other activities outside the congregation. The literature on this subject suggests that congregational small group involvement at the individual level could hamper civic engagement, an outcome that would be contrary to this study's first hypothesis. It could also be that congregations with greater levels of overall small group involvement may create insular social networks that decrease civic engagement, contrary to hypothesis 2 . Finally, congregations with greater levels of small group involvement may create insular contexts within which the positive effect of small group involvement is reduced, a pattern contrary to hypothesis 3 . Therefore, building on prior work, both increases and decreases in the likelihood of civic engagement are theoretically possible when congregations encourage small group participation.

\section{Data}

This study draws on data from the 2001 U.S. Congregational Life Survey (US CLS). The US CLS is a random sample of U.S. congregations. The study uses a national sample of churches drawn by National Opinion Research Center (NORC) using the 2000 General Social Survey (GSS). Using hypernetwork sampling procedures, individuals in the GSS who reported attending worship services at least once per year were asked to identify their primary

\footnotetext{
${ }^{2} \mathrm{We}$ are grateful to an anonymous reviewer for suggesting this literature.
} 
congregational affiliation. A list of 1,600 religious congregations resulted and were contacted. Sixty-one percent agreed to participate and 54 percent of those who agreed to participate returned completed forms. This resulted in a 33 percent response rate for all invited congregations. The response rate poses some limitations to the generalizability of the findings with regard to point estimates. However, we are focused on the relationships between variables and the direction of those relationships. Survey response rates have been found not to have substantial impacts on the accuracy of regression betas (American Association for Public Opinion Research 2008; Singer 2006). Additionally, the US CLS compares favorably with the 1998 National Congregations Study (Hill and Olson, 2009).

The US CLS collected information on 122,404 individuals in 424 congregations. The attendee survey was administered to all congregants present at worship services held on April 29, 2001. A knowledgeable church leader also completed a survey for each congregation that supplied details about the congregation such as denominational affiliation, size, and history. Therefore, the US CLS is a hierarchically structured data set that nests individuals within their respective congregations (Woolever and Bruce, 2002). This unique data structure allows for tests of whether congregational attributes are associated with individual-level outcomes. After recoding and listwise deletion for missing cases at either the congregational or individual level, the final analysis is based on 83,564 individual cases and 408 congregations. Roughly 9.9 percent of individuals did not give information about income. There were no missing values in the following variables: child in home, race, and age. Aside from income, missing values for the remaining study variables was relatively low (below 1.9 percent).

\section{Dependent Variables}


We use four measures of civic engagement. One measures whether congregants are civically engaged through their congregation. The three remaining dependent variables focus on whether congregants are civically engaged with groups not affiliated with their congregation. In this analysis, civic engagement is defined as either direct involvement or providing financial donations, measures standard in the literature (Brooks 2003; Campbell and Yonish 2003). The first dependent variable accounts for whether congregants are involved in community service, social justice, or advocacy activities associated with the congregation. The second measure determines if congregants are involved in social service or charity groups not connected to the congregation. The third dependent variable is similar to the second but asks if congregants are associated with advocacy, justice, or lobbying groups not connected to the congregation. The final variable asks if congregants have, in the past 12 months, donated money to a charitable organization other than their congregation. Response options for all items are yes (1) or no (0) given that respondents were only provided these two possible options in this dataset. ${ }^{3}$

\section{Independent Variables}

The independent variables of interest are small group participation at the individual level and overall small group participation at the congregation level. Small group involvement at the individual level is a dichotomous measure - yes (1) or no (0) - indicating if the respondent is involved in a prayer, discussion, or Bible study group. The congregation-level measure of overall small group participation is constructed using individual level data. It is the proportion of individuals in each congregation that are involved in a small group (prayer, discussion, or Bible study group). Larger proportions signify a greater level of involvement in small groups across the congregation. Therefore, a congregation with a proportion close to 1 has high congregation-

\footnotetext{
${ }^{3}$ We discuss the implications of this coding in the discussion section. Dichotomous variables are commonly used in congregational studies using the US CLS (Dougherty and Whitehead 2010; Draper 2014; Martinez and Dougherty 2013; Stroope 2011a, 2011b; Stroope and Baker 2014).
} 
level small group participation, and a congregation with a score close to 0 has low congregationlevel small group involvement.

\section{Control Variables}

Measures used in past research on civic engagement are included in the analysis (Putnam 2000; Putnam and Campbell 2010). At the individual level we include controls for age, race (White $=1)$, gender $($ Female $=1)$, marital status (Married $=1)$, children in the home $($ yes $=1)$, education, income, religious service attendance, devotional practice, views of the Bible, theological exclusivity, and a measure of whether the congregation provides opportunities for civic engagement. Age is measured continuously and is limited to those respondents over the age of 18. Education is measured on an eight-point scale from "no formal education" to "graduate degree." Income is a six-point scale ranging from $1=$ "less than $\$ 10,000 "$ to $6=" \$ 100,000$ plus." Religious service attendance is a seven-point item that ranges from $1=$ "This is my first time" to 7 = "I attend more than once a week." Devotional practice refers to how often respondents spend time in private devotional activities. Possible responses range from $1=$ "Never" to 6 = "Every day." Also included is biblical literalism. Participants that believe the Bible is the actual word of God and should be interpreted literally are coded as a 1, else 0 . Theological exclusivity measures the degree to which congregants agree that all religions are equally good ways of finding ultimate truth (this 5-point item is reverse coded). The final individual-level control measures if the congregation offers any activities that reach out to the wider community (yes $=1$ ).

At the congregation level we control for size of congregation, average educational attainment, region of the country (South $=1$ ), and religious tradition. Size is logged due to nonnormal distribution. Average educational attainment is the mean of individual-level education for 
each congregation. Religious tradition is measured using a series of dichotomous variables that places each congregation into the categories of "Evangelical Protestant," "Black Protestant," "Mainline Protestant," "Catholic," "Jewish,” or “Other" (Steensland et al. 2000). For each analysis Mainline Protestants serves as the contrast category.

\section{Analysis}

We use multilevel modeling to examine relationships between variables at different levels (i.e., congregation and individual) (Raudenbush and Bryk 2002). Multilevel modeling adjusts for biased standard errors that are present when investigating multilevel associations using standard regression techniques. When data nest individuals within groups, traditional regression assumptions are violated. Multilevel modeling corrects for this by "recognizing the partial interdependence of individuals within the same group" (Hofmann

1997:726). Individual-level effects can also be moderated by contextual factors in multilevel modeling. In other words, the slopes of individual-level effects are permitted to vary across contextual unites and those slopes become outcomes predicted by contextual effects (Raudenbush and Bryk 2002:117-119). Because this study's dependent variables are dichotomous, we use multilevel logistic regression.

\section{Results}

Table 1 displays the descriptive statistics for the sample used in this analysis. About 24 percent of respondents in the US CLS participate in community civic activities connected to their congregation. Almost 30 percent participate in a community service, social service, or advocacy group not connected to their congregation. Only 6 percent participate in advocacy, justice, or lobbying groups that are unconnected to the congregation. A much larger percentage, 76 percent, report donating money to a charitable organization other than their congregation. We also find 
that 27 percent of the respondents in this sample are involved in a small group connected to their congregation. At the congregational level, the average level of small group participation is 0.36 . This means that, on average, congregations have over a third of their congregants involved in a prayer, discussion, or Bible study group.

***Table 1 about here***

Before reporting multivariate results, the results (not shown in tables) of an empty multilevel model indicate the following. All four civic engagement outcomes vary across congregations. In these unconditional models, there is statistically significant $(\mathrm{p}<.001)$ congregation-level variance in the average log odds of all four civic engagement measures (Raudenbush and Bryk 2002). Intra-class correlations (ICCs) in empty models are as follows: .096 (congregational civic activities), .064 (social service), .088 (advocacy), and .101 (donation). In other words, 9.6 percent, 6.4 percent, 8.8 percent, and 10.1 percent of the total variance in these forms of civic engagement can be attributed to the congregation to which individuals belong. These are standard or sizeable ICCs in comparison with values typically 5 percent and upwards in multilevel research (Snijders and Bosker 1999: 46).

Table 2 presents the results from multilevel models. The first model analyzes the likelihood of participating in congregational activities aimed at civic interests. Net of all other effects in the model, individuals involved in a small group are more likely to participate in congregational civic activities. Individuals in congregations with higher overall small group participation are also more likely to participate. The cross-level interaction of individual small group involvement and overall small group involvement is statistically significant and negative. Figure 1 shows the predicted probability of congregational civic activity involvement against the proportion of a congregation's membership that are small group members compared to small 
group nonmembers. Differences in the likelihood of small group participants versus nonparticipants to engage in congregational civic activities are conditioned by congregation-level small groups such that small group members are less likely to engage in congregational civic activities in high small group congregations compared to low small group congregations. Small group nonparticipants are slightly more likely to engage in congregational civic activities in high small group congregations compared to low small group congregations.

However, as the figure illustrates, even though the civic engagement gap across the small group participant/nonparticipant divide shrinks in high small group congregations, it is worth remembering that small group participants always have a higher probability of congregational civic activities than small group nonparticipants at all levels congregation-level small groups. Also worth pointing out, average civic engagement in this model is lower in high small group congregations. Importantly, this cross-level interaction effect holds net of various individuallevel characteristics and important congregation covariates such as religious tradition.

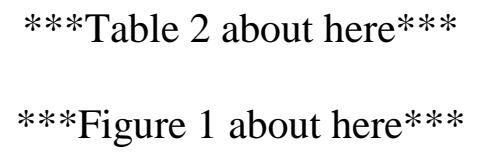

The second model in table 2 focuses on participation in social service or charity groups not connected to the congregation. Individuals involved in a small group have greater odds of involvement in social service or charity groups even if these forms of civic engagement are outside the congregation. The overall small group participation in a congregation is not significantly associated with this type of civic engagement. The interaction between the individual and congregational small group measures is significant and negative. Figure 2 depicts this interaction effect. Differences in the likelihood of small group participants versus nonparticipants to engage in social service are moderated by congregation-level small groups 
such that small group members are less likely to engage in social service in high small group congregations compared to low small group congregations. Small group nonparticipants are neither more nor less likely to engage in social service in low small group congregations compared to high small group congregations. Small group participants always have a higher probability or at least roughly equal probability of social service than small group nonparticipants at all levels congregation-level small groups. However, the social service gap across the small group participant/nonparticipant divide shrinks to a negligible difference in high small group congregations. Similar to model 1, average social service in model 2 is lower in high small group congregations. This cross-level interaction is robust to the inclusion of an array of important individual- and congregation-level covariates.

$* * *$ Figure 2 about here $* * *$

The third model in table 2 analyzes participation in advocacy, justice, or lobbying groups not affiliated with the congregation. As in the prior models, small group involvement is significantly and positively associated with greater odds of civic engagement, the overall small group participation of a congregation does not carry a significant effect, and the cross-level interaction between the individual and congregational small group measures is statistically significant and negative.

Figure 3 illustrates this interaction effect. Differences in the likelihood of small group participants versus nonparticipants to engage in social service are conditioned by congregationlevel small groups such that small group members are less likely to engage in advocacy in high small group congregations compared to low small group congregations. Like prior models, small group nonparticipants are neither more nor less likely to engage in social service in low small group congregations compared to high small group congregations. Different than the previous 
two models, not only does the civic engagement gap across the small group

participant/nonparticipant divide narrow as congregation-level small group involvement increases, but the slope for small group participants also crosses over that of small group nonparticipants. This cross-over appears at above average levels of congregation-level small group participation. Different than models 1 and 2, small group participants do not always have a higher probability of advocacy at all scores of congregation-level small groups. As members of congregations with high overall small group participation, small group nonparticipants are more likely than small group participants to engage in advocacy. As with the previous models, this cross-level interaction is significant after adjusting for important covariates.

$* * *$ Figure 3 about here $* * *$

The final model investigates donating money to a charitable organization other than the respondent's congregation. As before, individuals involved in a small group are more likely to be civically engaged (in this instance, giving financial donations to organizations outside the congregation). Different than prior models, the coefficient for overall congregation-level small group participation is not only negative, but is also statistically significant. However, the crosslevel interaction between individual- and congregation-level small group participation is not significant. This pattern of effects indicates as congregation-level small group participation increases, individuals are on average less likely to engage in outside financial donations. This contextual effect is not significantly different for small group participants compared to nonparticipants. Note, however, that at the individual level, small group participations are more likely to donate money outside the congregation. ${ }^{4}$

\footnotetext{
${ }^{4}$ We performed a series of supplementary analyses to ensure that our findings across all four outcomes were robust. We included several potentially important control variables: (1) civic denomination (Lee and Bartkowski 2004; Tolbert et al. 1998); (2) theological orientation of the congregation (taken from the congregational profile and measured as dummies for conservative [reference], moderate, and liberal); (3) proportion biblical literalist; (4) mean
} 


\section{Discussion}

This study provides evidence that small group members in religious congregations are consistently more likely to be civically engaged than individual who are not members of a small group, consistent with prior research. Small group members are more likely to engage in all four civic engagement outcomes measured in this study, (1) civic service activities provided by the congregation, (2) volunteering at social service or charity groups not connected to their congregation, (3) involvement in advocacy and justice groups not connected to their congregation, and (4) financial giving to charitable organizations beyond their congregation. These results support Hypothesis 1 and suggest that small group involvement increases the likelihood of civic engagement both through and outside the congregation.

The above results resonate with social mechanisms developed in prior literature. The increases in individuals' social networks resulting from small group participation alert them to needs in the community, increase their chances at being recruited, and keep them accountable to serving in some way (Wuthnow 1991, 1994b). These groups are also arenas for the cultivation of skills necessary for civic engagement (Verba et al. 1995). Small groups also serve as a venue where religiosity is encouraged, which increases the likelihood of civic engagement (Wuthnow 1990). Small groups are a mix of both public and private religious activities which prior research identifies as highly predictive of civic engagement (Smidt et al. 2008).

While small group involvement at the individual level is consistently associated with a greater likelihood of civic engagement, a uniformly consistent pattern does not emerge from this

income; (5) proportion white; (6) proportion of members reporting "no congregational civic activities; and (7) meanimputed income dummies with an indicator variable flag (Cohen et al. 2002). The pattern of effects in these supplementary models provide a more conservative test of our hypotheses. Our focal findings do not appear to be sensitive to these alternate specifications. One exception is that in the congregational civic activities model, the positive slope for individuals not involved in a small group becomes almost flat when civic denomination is controlled instead of religious tradition dummies. 
study in the case of overall small group participation at the congregation level; Hypothesis 2 regarding congregation-level effects receives support in only two of the models, and in opposite directions. Individuals in congregations with higher levels of overall small group participation are more likely to participate in civic service activities provided by the congregation, while they are no more likely to volunteer at social service or charity groups not connected to their congregation, or involve themselves in advocacy and justice groups not connected to their congregation. Individuals in congregations with high levels of small group participation, however, are less, not more, likely to donate money to charitable organizations beyond their congregation. The effects of small group involvement are the most consistent at the individual level, not the congregation level and where contextual effects are present at the congregation level, one runs counter to the direction hypothesized. This somewhat unexpected finding will be returned to below.

This study also theorized and measured the interplay between overall small group participation and individual small group participation. After taking into account the moderating role of individual-level small groups, high overall levels of small group participation are not only unassociated with most types of civic engagement analyzed in this study, but appear to dampen the effects of small group involvement at the individual level. Regarding participation in civic activities provided by the congregation, involvement in social service or charity groups not connected to their congregation, or participation in advocacy and justice groups not connected to their congregation, the beneficial effect of being in a small group is diminished in high small group congregations. For church-based civic activities and social service, small group participants still have a civic edge (albeit reduced) on small group nonparticipants in high small group churches. In the case of advocacy groups, however, small group members and 
nonmembers trade places as the church's civic exemplars as overall small group participation rises. Turning to effects on outside financial donations, there is no significant cross-level interplay between overall small group participation and individual small group participation. The positive effect of small group participation is the same whether in a congregation with a smaller or larger proportion of fellow congregants involved in a small group. Taken together, this set of findings leaves Hypothesis 3 unsupported. Further, this set of findings is opposite of our predictions.

Contrary to both the "absorptive capacity" framework put forward by Tsai (2001) and the ratification hypothesis following from moral communities theory, this study's contextual and cross-level effect findings indicate that congregations with high levels of overall small group participation create a context within which the civic effects of small groups become weaker. Not only does this set of findings complicate prior research focused on small groups and congregants' internal voluntary behavior (Whitehead 2010) as well as research finding congregants' activity in church organizations predicts greater involvement in civic organizations (Schwadel 2005), it suggests thinking more deeply about the organizational level and how a potential context-level dampening operates in relation to civic engagement.

The network density found in congregations with high overall small group participation may serve to insulate congregants, limiting their interaction with those outside of the group. As in past literature highlighting the "dark side" of social capital, intra-group social network density (i.e., bonding social capital) can be detrimental to civic engagement (Fiorina 1999; Putnam 2000). The findings in this study suggest that a culture or structure of high small group participation at the organizational level can foster the kind of bonding social capital that-especially for those enmeshed in its small group structure--can limit bridging social capital. This 
socially encapsulating organizational context results in lower civic engagement for those caught up in internal small groups. These findings also support the "crowding out" effect posited in the economics of voluntary behavior literature. The increased opportunity costs of civic engagement, above and beyond the time and energy given to participating in a congregational small group, leads to small group members choosing one or the other (Frey 1997a, 1997b; Frey and Götte 1999; Menchik and Weisbrod 1987). In this case, small group members in high overall small group participation congregations neglect civic engagement.

The above line of reasoning makes further sense in light of Thumma and Travis' (2007) observation regarding the intentionality of congregational leaders in drawing congregants into small groups for the sake member retention, network density, and overall internal organizational participation. Congregations that use a church-wide system of small groups for the sake of internal organizational health may find that such a structure does not translate into greater civic engagement for congregants and may in fact work against civic engagement. Even if congregations offer members a range of community volunteering opportunities, these may be offered, in part, as a selling point for recruiting and retaining members—internal organizational health. Offering such programs can also help congregations with image management. Local community members may criticize churches as being big buildings that sit in the community taking up space and money but giving nothing back. Members of a congregation with participants in various programs may counter by pointing to how members of their congregation serve the community through civic programs. Congregations can harness the civic small group participants for the sake of garnering member attachment to the congregation and maintaining a positive image for the congregation in the community. 
Therefore, if congregations are highly intentional about self-structuring for the sake of internal organizational health, an unintended consequence may be the crowding out of the civic activities of members drawn up in the congregations' small group system. While congregationlevel small group structures appear to have internally beneficial effects (Whitehead 2010), when considering effects on civic outcomes these same structures appear to socially encapsulate and isolate, redirecting or crowding out voluntary service away from the community and toward the immediate organization. Pastors whose faith instructs them to work for the good of the needy, yet who are also pressed to grow their congregation numerically and financially, may be tempted to trade off the civic pitfalls of congregation-wide small groups for the internal organizational benefits. The extent to which leaders are grappling with this tension and knowingly making this trade off is an area for further research. Additional case studies and qualitative research on this topic and the "crowding out" effect as an organizational dynamic is also warranted. Nevertheless, in this vein, pastors may be especially concerned about members giving finances to the congregation versus other causes. This study's finding that overall small group participation has significant negative direct effects on non-congregation financial giving is at least suggestive for this issue.

One consistent finding across all models that deserves mention is the negative and significant association between biblical literalism and civic engagement. Individuals who believe the Bible should be taken literally, word for word, are less likely than non-literalists to give of their time, skills, and money to organizations outside the congregation. As Hempel et al. (2012) demonstrate, theological conservatism is negatively related to the propensity to trust "unknown others". Our findings dovetail with theirs and are consistent with the idea that people committed to a particular strand of theological conservatism are less likely to engage in broader civic life, 
likely due to lower levels of generalized trust (Hempel, Matthews, and Bartkowski 2012). ${ }^{5}$ Congregations with primarily exclusive theologies are also found to encourage bonding social capital at the expense of bridging social capital (Scheitle and Adamczyk 2009; Schwadel 2005).

Despite the obvious strengths of the U.S. Congregational Life Survey in examining contextual effects within religious congregations, several limitations deserve mention. First, the specific type of small group investigated in this study does not capture the breadth of possible small groups. There could be small groups within a congregation that organize around goals other than prayer, discussion, or Bible study. Furthermore, there are myriad forms of small groups that are unconnected to congregations, both religious and secular; the present study is unable to account for the broad range of small group types that have been catalogued (Marcello and Perrucci 2009; Wuthnow 1994b). Future research could build on our findings by using multilevel data with more fine-grained measures of the different types of small groups. Second, we are unable to measure the homogeneity/heterogeneity of the small groups themselves within each congregation. Future research would benefit from examining the similarity of participants of each small group. Third, although outside the scope of our research question, it is impossible to determine whether the measures of noncongregational civic engagement are secular or religious. The data do not permit us to rule out the possibility that respondents are volunteering and donating to religious organizations that are not a part of their congregation. We are unable to confirm or deny whether religion, in the form of religious small group involvement, increases or decreases civic engagement with purely secular causes as past research suggests (Brooks 2003; Campbell and Yonish 2003; Ruiter and De Graaf 2006; Smidt et al. 2008). To move beyond these data limitations and advance these concerns, future multilevel congregation-member data

\footnotetext{
${ }^{5}$ Due to limitations in the US CLS dataset we are unable to construct the same theological conservatism index as Hempel and colleagues (2012).
} 
collection efforts should incorporate measures of congregation-based, religious non-congregation based, and nonreligious civic engagement. Fourth, we were forced to use dichotomous civic engagement measures. It is possible that a "ceiling effect" is present in our findings. Measures that allow for more variability might very well pick up more of a relationship between organizational small group structure and individual civic engagement. ${ }^{6}$ Fifth, prior research on civic engagement points to the importance of social trust in predicting civic involvement (Jennings and Stoker 2004; Uslaner and Brown 2005; Uslaner and Conley 2003). However, we are unable to measure respondents' levels of social trust. Future research should incorporate measures that move beyond these limitations.

Finally, as in many studies relying on available cross-sectional multilevel data, the inability to measure change over time is a limitation in the present study. We cannot rule out the possibility that individuals with an underlying "joiner" orientation are involved in a wide array of voluntary behavior and groups including church-based small groups (Norris and Inglehart 2004; Putnam 2000). However, recent research analyzing 10 waves of panel data with fixed effects panel models and cross-lagged structural equation models shows that while a reciprocal relationship exists between religious service attendance and voluntary engagement, the effect of religious involvement on voluntary engagement is larger (Meissner and Traunmüller 2010). In light of these findings, while some individuals who are civically-inclined may join small groups, theory and new evidence suggests that the relationship between small group membership and civic engagement is likely not entirely due to selection processes. Future research could further bolster these findings by employing panel data on congregations, small groups, and members to understand the trajectory of individuals' civic engagement behavior in relation to their small group involvement. Despite these limitations, the U.S. Congregational Life Survey is an

\footnotetext{
${ }^{6} \mathrm{We}$ are grateful to an anonymous reviewer for this suggestion.
} 
incredibly unique dataset that allows for examinations of the effects of organizational context within religious congregations.

The present study adds to a growing research literature on religion and civic engagement. Using a large, national sample of congregations and members in the United States, we find that an individual's involvement in a congregation-based small group is associated with increased odds that an individual will be civically engaged. Small group participants are more likely to report civic involvement both through and outside their congregation. Small group participants are also more likely to report giving money to organizations outside their congregation. There is also evidence of a "crowding out" effect given high overall levels of small group participation in congregations. Increases in network density and insularity along with increased opportunity costs may encourage congregants to be less likely to give money to groups not connected to the congregation. Additionally, in congregations where overall small group involvement is higher, the positive effects of small group participation on civic engagement are in many cases diminished, in one instance below that of individuals not in small groups. Taking both levels of analysis in view, small groups are not uniformly good or bad for civic engagement. Nevertheless, a culture of small groups in a congregation does not appear to benefit a surrounding community. In some instances, benefits to the local community diminish. 


\section{References}

American Association for Public Opinion Research. 2008. "Do response rates matter?" http://www.aapor.org.

Becker, P.E. and P. Dhingra. 2001. Religious involvement and volunteering: Implications for civil society. Sociology of Religion 62(3):315-35.

Beyerlein, K. and J.R. Hipp. 2006. From pews to participation: The effect of congregation activity and context on bridging civic engagement. Social Problems 53(1):97-117.

Bird, W. and S. Thumma. 2011. A new decade of megachurches: 2011 Profile of large attendance churches in the United States. Hartford Institute for Religion Research Summary Report. Accessed on January 09, 2013 at: http://hirr.hartsem.edu/megachurch/megachurch-2011-summary-report.htm

Bjarnason, T., T. Thorlindsson, I.D. Sigfusdottir, and M.R. Welch. 2005. Familial and religious influences on adolescent alcohol use: A multi-level study of students and school communities. Social Forces 84(1):375-390.

Borgonovi, F. 2008. Divided we stand, united we fall: Religious pluralism, giving, and volunteering. American Sociological Review 73(1):105-128.

Brooks, A.C. 2003. Religious faith and charitable giving. Policy Review 121: 39-50.

Campbell, D. and S. Yonish. 2003. Religion and volunteering in America. In Religion as social capital: Producing the common good, ed. C. E. Smidt, 82-106. Waco, TX: Baylor University Press.

Clemmons, W.P. and H. Hester. 1974. Growth through groups. Nashville, TN: Broadman Press.

Cohen, J., P. Cohen, S.G. West, and L.S. Aiken. 2002. Applied multiple regression/correlation analysis for the behavioral sciences. Third. Routledge.

Dougherty, K. and A.L. Whitehead. 2011. A place to belong: Small group involvement in religious congregations. Sociology of Religion 72(1):91-111.

Draper, S. 2014. Effervescence and solidarity in religious organizations. Journal for the Scientific Study of Religion 53(2):229-248.

Ellison, C.G. 1992. Are religious people nice people? Evidence from the national survey of black Americans. Social Forces 71:411-30.

Fiorina, M.P. 1999. Extreme voices: A dark side of civic engagement. In Civic engagement in American democracy eds. Theda Skocpol and Morris P. Fiorina, 395-425. Washington, D.C.: Brookings Institution Press. 
Frey, B.S. 1997a. On the relationship between intrinsic and extrinsic work motivation. International Journal of Industrial Organization 15:427-439.

Frey, B.S. 1997b. Not Just for the Money: An Economic Theory of Personal Motivation. Cheltenham: Edward Elgar.

Frey, B.S. and Götte, L. 1999. Does pay motivate volunteers? University of Zurich, Institute for Empirical Research in Economics, working paper, n. 7.

Hempel, L.M., T. Matthews, and J. Bartkowski. 2012. Trust in a "fallen world": The case of Protestant theological conservatism. Journal for the Scientific Study of Religion 51(3):522-541.

Hill, J.P. and D.V.A. Olson. 2009. Market share and religious competition: do small market share congregations and their leaders try harder? Journal for the Scientific Study of Religion 48:629-649

Hofmann, D.A. 1997. An overview of the logic and rationale of hierarchical linear models. Journal of Management 23(6):723-44.

Jennings, M.K. and L. Stoker. 2004. Social trust and civic engagement across time and generations. Acta Politica 39(4):342-379.

Lam, P.Y. 2002. As the flocks gather: How religion affects voluntary association participation. Journal for the Scientific Study of Religion 41:405-22.

Lee, M.R., and J.P. Bartkowski. 2004. Love thy neighbor? Moral communities, civic engagement, and juvenile homicide in rural areas. Social Forces 82(3):1001-1035.

Lewis, V. A., C. A. MacGregor, \& R. D. Putnam. 2012. Religion, networks, and neighborliness: The impact of religious social networks on civic engagement. Social Science Research 42(2): 331-346.

Lim, C., and MacGregor, C. A. 2012. Religion and volunteering in context: Disentangling the contextual effects of religion on voluntary behavior. American Sociological Review 77(5): 747-779.

Loveland, M., D. Sikkink, D. Myers, and B. Radcliff. 2005. Private prayer and civic involvement. Journal for the Scientific Study of Religion 44:1-14.

Marcello, M.K. and R. Perrucci. 2009. Civic engagement among small-group participants: Creating community or self-absorption? Sociological Spectrum 29:677-99.

Martinez, B. C. and Dougherty, K. D. 2013. Race, belonging, and participation in religious congregations. Journal for the Scientific Study of Religion 52(4):713-732. 
Meissner, P. and R. Traunmüller. 2010. Church attendance and voluntary engagement: The anatomy of a causal mechanism. Paper presented at the SOEP-2010 $9^{\text {th }}$ International German Socia-Economic Panel User Conference, Berlin, June 30 to July 1.

Menchik, P.L. and Weisbrod, B.A. 1987. Volunteer labor supply. Journal of Public Economics 32:159-183.

Norris, P. and R. Inglehart. 2004. Sacred and secular: Religion and politics worldwide. Cambridge, MA: Cambridge University Press.

Putnam, R. D., \& Campbell, D. E. 2010. American grace: How religion divides and unites us. New York: Simon \& Schuster.

Putnam, R. 2000. Bowling along: The collapse and revival of American community. New York: Simon \& Schuster.

Raudenbush, S.W. and A.S. Bryk. 2002. Hierarchical linear models: Applications and data analysis methods, $2^{\text {nd }}$ ed. Thousand Oaks, CA: Sage Publications.

Ruiter, S. and N.D. De Graaf. 2006. National context, religiosity, and volunteering: Results from 53 countries. American Sociological Review 71:191-210.

Scheitle, C.P. and A. Adamczyk. 2009. It takes two: The interplay of individual and group theology on social embeddedness. Journal for the Scientific Study of Religion. 48(1):129.

Scheitle, C.P. and R. Finke. 2008. Maximizing congregational resources: Selection versus production. Social Science Research. 37(3):815-27.

Schwadel, P. 2005. Individual, congregational and denominational effects on church members' civic participation. Journal for the Scientific Study of Religion 44(2):159-71.

Singer, E. 2006. Special issue on nonresponse bias in household surveys. Public Opinion Quarterly 70(5):639-810.

Snijders, Tom A.B., Bosker, Roel J., 1999. Multilevel analysis: An introduction to basic and advanced multilevel modeling. Thousand Oaks, CA: Sage Publications.

Smidt, C., K.R. den Dulk, J.M. Penning, S.V. Monsma, and D.L. Koopman. 2008. Pews, prayers, and participation: Religion and civic responsibility in America. Washington, D.C.: Georgetown University Press.

Stark, R. and R. Finke. 2000. Acts of faith: Explaining the human side of religion. Berkeley: University of California Press. 
Steensland, B., J.Z. Park, M.D. Regnerus, L.D. Robinson, W. B. Wilcox, and R.D. Woodberry. 2000. The Measure of American Religion: Toward Improving the State of the Art. Social Forces 79(1):291-318.

Stroope, S. 2011a. How culture shapes community: Bible belief, theological unity, and a sense of belonging in religious congregations. The Sociological Quarterly 52(4):568-592.

Stroope, S. 2011b. Education and religion: Individual, congregational, and cross-level interaction effects on biblical literalism. Social Science Research 40 (6):1478-1493.

Stroope, S. 2012. Social networks and religion: The role of congregational social embeddedness in religious belief and practice. Sociology of Religion 73(3):273-298.

Stroope, S. and Baker, J. O. 2014. Structural and cultural sources of community in American congregations. Social Science Research 45:1-17.

Thumma, S. and D. Travis. 2007. Beyond megachurch myths. San Francisco, CA: Jossey-Bass.

Tolbert, C.M., T.A. Lyson, and M.D. Irwin. 1998. Local capitalism, civic engagement, and socioeconomic well-being. Social Forces 77:401-27.

Tsai, W. 2001. Knowledge transfer in intraorganizational networks: effects of network position and absorptive capacity on business unit innovation and performance. The Academy of Management Journal 44:996-1004.

Uslaner, E.M. and M. Brown. 2005. Inequality, trust, and civic engagement. American Politics Research 33(6):868-894.

Uslaner, E.M. and R.S. Conley. 2003. Civic engagement and particularized trust: The ties that bind people to their ethnic communities. American Politics Research31(4):331-360.

Verba, S., K.L. Schlozman, and H.E. Brady. 1995. Voice and equality: Civic voluntarism in American politics. Cambridge, MA: Harvard University Press.

Wallace, J.M. et al. 2007. Religiosity and adolescent substance use: The role of individual and contextual influences. Social Problems 54(2):308-327.

Whitehead, A.L. 2010. Financial commitment within federations of small groups: The effect of cell-based congregational structure on individual giving. Journal for the Scientific Study of Religion 49(4):640-656.

Woolever, C. and Bruce, D. 2002. A field guide to US congregations: Who's going where and why. Louisville, KY. Westminster John Knox Press.

Wuthnow, R. 1990. Religion and the voluntary spirit in the United States: Mapping the terrain. In Faith and philanthropy in America: Exploring the role of religion in America's 
voluntary sector, eds. Robert Wuthnow and Virginia Hodgkinson et al., 3-21. San Francisco, CA: Jossey-Bass.

Wuthnow, R. 1991. Acts of compassion: Caring for others and helping ourselves. Princeton, NJ: Princeton University Press.

Wuthnow, R. 1994a. “I come away stronger”: How small groups are shaping American religion. Grand Rapids, MI: William B. Eerdmans Publishing.

Wuthnow, R. 1994b. Sharing the journey: Support groups and America's quest for community. New York: Free Press.

Wuthnow, R. 1996. Christianity and civil society: The Contemporary Debate. Valley Forge, PA: Trinity Press International. 
Table 1: Descriptive statistics (weighted data)

\begin{tabular}{|c|c|c|c|c|}
\hline & Mean & SD & Min & $\operatorname{Max}$ \\
\hline \multicolumn{5}{|l|}{ Level 1 (Individual) $(\mathrm{N}=83,564)$} \\
\hline Congregational Civic Activities & 0.24 & --- & 0 & 1 \\
\hline Social Service $\dagger$ & 0.30 & --- & 0 & 1 \\
\hline Advocacy Group $\dagger$ & 0.06 & --- & 0 & 1 \\
\hline Donate Money† & 0.76 & --- & 0 & 1 \\
\hline Small Group Involvement & 0.27 & --- & 0 & 1 \\
\hline Age & 50.51 & 16.20 & 18 & 100 \\
\hline White & 0.78 & --- & 0 & 1 \\
\hline Female & 0.60 & --- & 0 & 1 \\
\hline Married & 0.58 & --- & 0 & 1 \\
\hline Child in Home & 0.58 & --- & 0 & 1 \\
\hline Education & 5.65 & 1.72 & 1 & 8 \\
\hline Income & 3.66 & 1.48 & 1 & 6 \\
\hline Attendance & 5.71 & 1.18 & 1 & 7 \\
\hline Devotional Practice & 4.66 & 1.54 & 1 & 6 \\
\hline Biblical Literalist & 0.27 & --- & 0 & 1 \\
\hline Theological Exclusivity & 2.81 & 1.28 & 1 & 5 \\
\hline No Cong. Civic Activities & 0.07 & --- & 0 & 1 \\
\hline \multicolumn{5}{|l|}{ Level 2 (Congregational) $(\mathrm{N}=408)$} \\
\hline Overall Small Group Participation & 0.36 & --- & 0 & 1 \\
\hline Size (logged) & 4.52 & 1.18 & 2.20 & 8.59 \\
\hline South & 0.39 & --- & 0 & 1 \\
\hline Mean Educational Attainment & 5.02 & 0.82 & 2.18 & 7.34 \\
\hline Evangelical Protestant & 0.48 & --- & 0 & 1 \\
\hline Black Protestant & 0.03 & --- & 0 & 1 \\
\hline Mainline Protestant ${ }^{\mathrm{a}}$ & 0.30 & --- & 0 & 1 \\
\hline Catholic & 0.10 & --- & 0 & 1 \\
\hline Jewish & 0.003 & --- & 0 & 1 \\
\hline Other & 0.09 & --- & 0 & 1 \\
\hline
\end{tabular}

$\dagger$ Involvement outside of respondent's congregation

${ }^{a}$ Contrast category 
Table 2: The role of individual-level and overall congregation-level small group participation in explaining civic engagement; Unstandardized coefficients from multilevel logistic regressions

\begin{tabular}{|c|c|c|c|c|c|c|c|c|}
\hline & \multicolumn{2}{|c|}{ Cong. Civic Activities } & \multicolumn{2}{|c|}{ Social Service } & \multicolumn{2}{|c|}{ Advocacy Group } & \multicolumn{2}{|c|}{ Donate Money } \\
\hline & Coefficient & T-ratio & Coefficient & T-ratio & Coefficient & T-ratio & Coefficient & T-ratio \\
\hline \multicolumn{9}{|l|}{ Level 1 (Individual) } \\
\hline Small Group Involvement & $1.32 * * *$ & 24.62 & $0.65^{* * *}$ & 12.67 & $0.65 * * *$ & 7.67 & $0.40 * * *$ & 7.55 \\
\hline Age & $0.01 * * *$ & 10.93 & $0.01 * * *$ & 11.70 & $0.01 * * *$ & 5.96 & $0.02 * * *$ & 34.53 \\
\hline White & -0.03 & -0.80 & $0.11 * * *$ & 3.83 & $-0.09 *$ & -1.73 & $0.53 * * *$ & 19.87 \\
\hline Female & $0.05^{*}$ & 2.47 & $0.17 * * *$ & 10.15 & $-0.21 * * *$ & -6.26 & $0.28 * * *$ & 15.13 \\
\hline Married & $0.10 * * *$ & 4.67 & $-0.09 * * *$ & -4.85 & $-0.26 * * *$ & -7.66 & $0.13 * * *$ & 6.83 \\
\hline Child in Home & 0.04 & 1.91 & -0.02 & -1.02 & 0.01 & 0.15 & -0.01 & -0.44 \\
\hline Education & $0.07 * * *$ & 10.18 & $0.16^{* * *}$ & 28.36 & $0.32 * * *$ & 26.37 & $0.18 * * *$ & 28.41 \\
\hline Income & $0.03 * * *$ & 4.08 & $0.09 * * *$ & 12.46 & $0.08 * * *$ & 6.32 & $0.37 * * *$ & 46.84 \\
\hline Attendance & $0.51 * * *$ & 34.03 & $0.02 * *$ & 3.00 & -0.00 & -0.13 & $0.01 *$ & 2.22 \\
\hline Devotional Practice & $0.14 * * *$ & 18.66 & $0.12 * * *$ & 20.17 & $0.08 * * *$ & 6.59 & $0.15 * * *$ & 24.00 \\
\hline Biblical Literalist & $-0.10 * * *$ & -3.88 & $-0.20 * * *$ & -9.02 & $-0.23 * * *$ & -4.77 & $-0.23 * * *$ & -10.38 \\
\hline Theological Exclusivity & $-0.06 * * *$ & -7.06 & $-0.06 * * *$ & -8.59 & $0.06 * * *$ & 4.54 & $0.07 * * *$ & 8.56 \\
\hline No Cong. Civic Activities & $-3.86 * * *$ & -17.58 & $-0.48 * * *$ & -12.34 & $-0.45 * * *$ & -5.36 & $-0.28 * * *$ & -8.31 \\
\hline \multicolumn{9}{|l|}{ Level 2 (Congregation) } \\
\hline $\begin{array}{l}\text { Overall Small Group Participation } \\
\text { (OSGP) }\end{array}$ & $0.66 * *$ & 2.6 & 0.21 & 1.07 & 0.27 & 0.87 & $-0.66^{* * * *}$ & -3.50 \\
\hline Size & $-0.227 * * *$ & -7.98 & $-0.10 * * *$ & -5.07 & $-0.17 * * *$ & -5.55 & $-0.05 *$ & -2.36 \\
\hline South & $0.13 *$ & 2.41 & -0.06 & -1.58 & -0.09 & -1.67 & $-0.08 *$ & -2.22 \\
\hline Mean Educational Attainment & $0.14 * * *$ & 3.58 & $0.15 * * *$ & 5.57 & $0.17 * * *$ & 4.23 & $0.11 * * *$ & 4.19 \\
\hline Evangelical Protestant & $-0.43 * * *$ & -5.29 & $-0.28 * * *$ & -4.71 & -0.10 & -1.11 & $-0.23 * * *$ & -4.08 \\
\hline Black Protestant & 0.08 & 0.57 & 0.15 & 1.42 & $0.33 *$ & 2.05 & -0.12 & -1.21 \\
\hline Catholic & -0.06 & -0.69 & $-0.18 * *$ & -2.98 & $0.29 * *$ & 3.14 & -0.02 & -0.37 \\
\hline Jewish & $1.29 * * *$ & 4.77 & 0.33 & 1.66 & 0.51 & 1.90 & 0.37 & 1.26 \\
\hline Other & $0.52 * * *$ & 3.84 & -0.14 & -1.49 & $0.64 * * *$ & 5.03 & $-0.37 * * *$ & -3.66 \\
\hline \multicolumn{9}{|l|}{$\begin{array}{l}\text { Cross-Level Interaction } \\
\text { (Level } 1 * \text { Level 2) }\end{array}$} \\
\hline Small Group*OSGP & $-0.95 * * *$ & -5.08 & $-0.90 * * *$ & -5.04 & $-1.29 * * *$ & -4.23 & -0.09 & -0.52 \\
\hline
\end{tabular}

$* p<.05 ; * * p<.01 ; * * * p<.001$ 


\section{Fig. 1. Cross-level interaction between congregation-level small groups and individual small group participation on congregational civic activities}

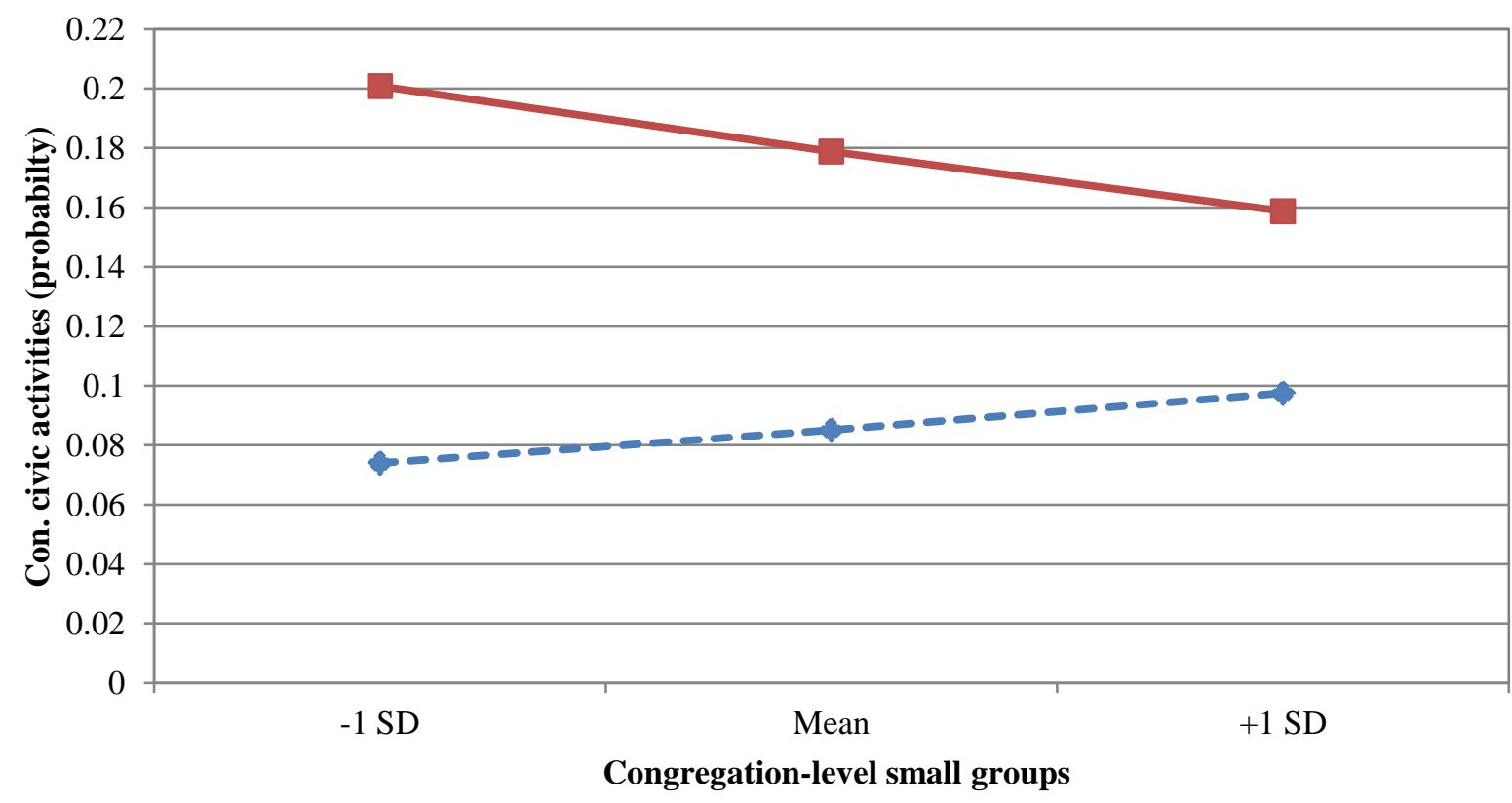

$-\infty$ Non-Small Group Participants $\quad-$ Small Group Participants 
Fig. 2. Cross-level interaction between congregation-level small groups and individual small group participation on social service

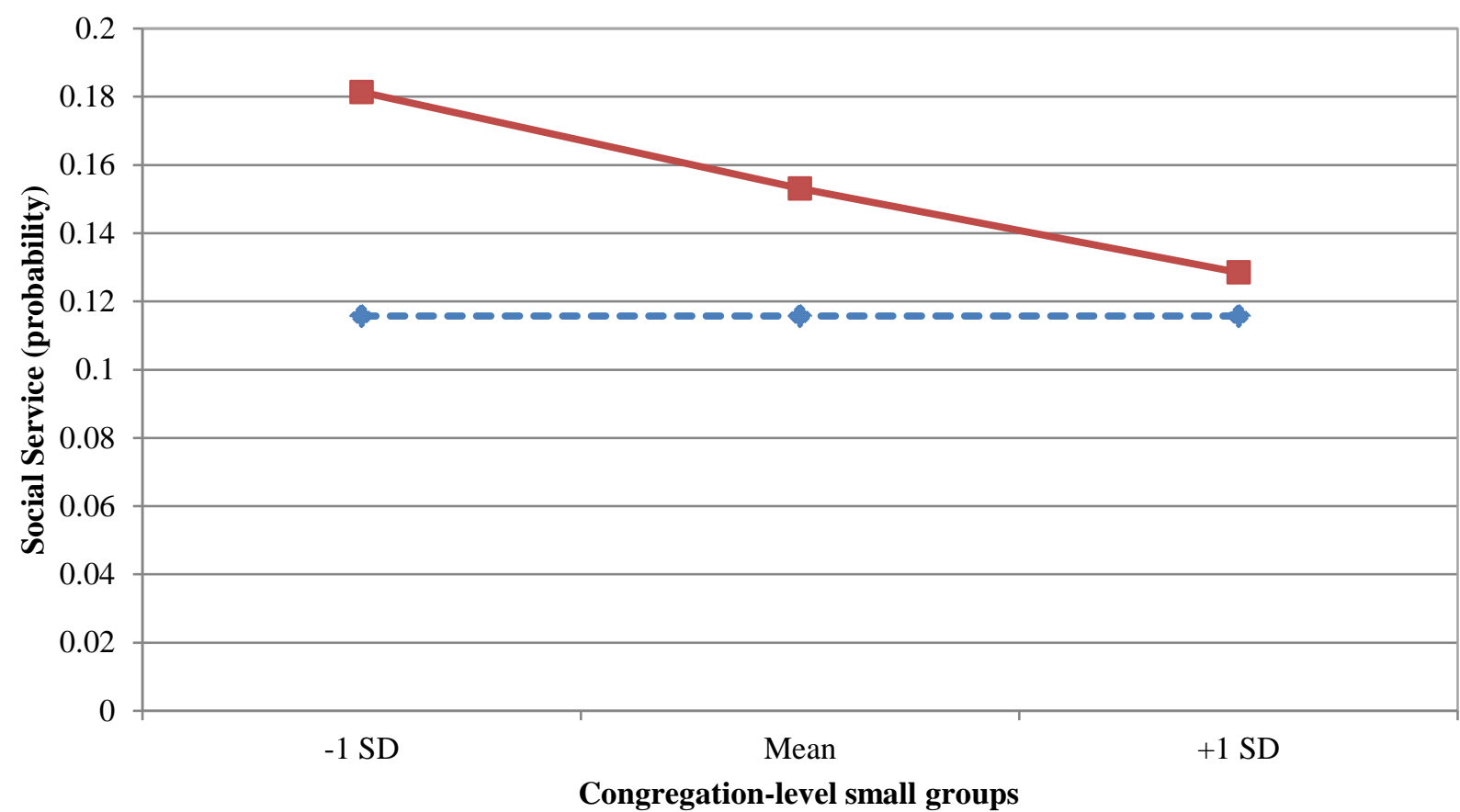

$-\infty$ Non-Small Group Participants $\quad-$ Small Group Participants 


\section{Fig. 3. Cross-level interaction between}

congregation-level small groups and individual small group participation on advocacy group

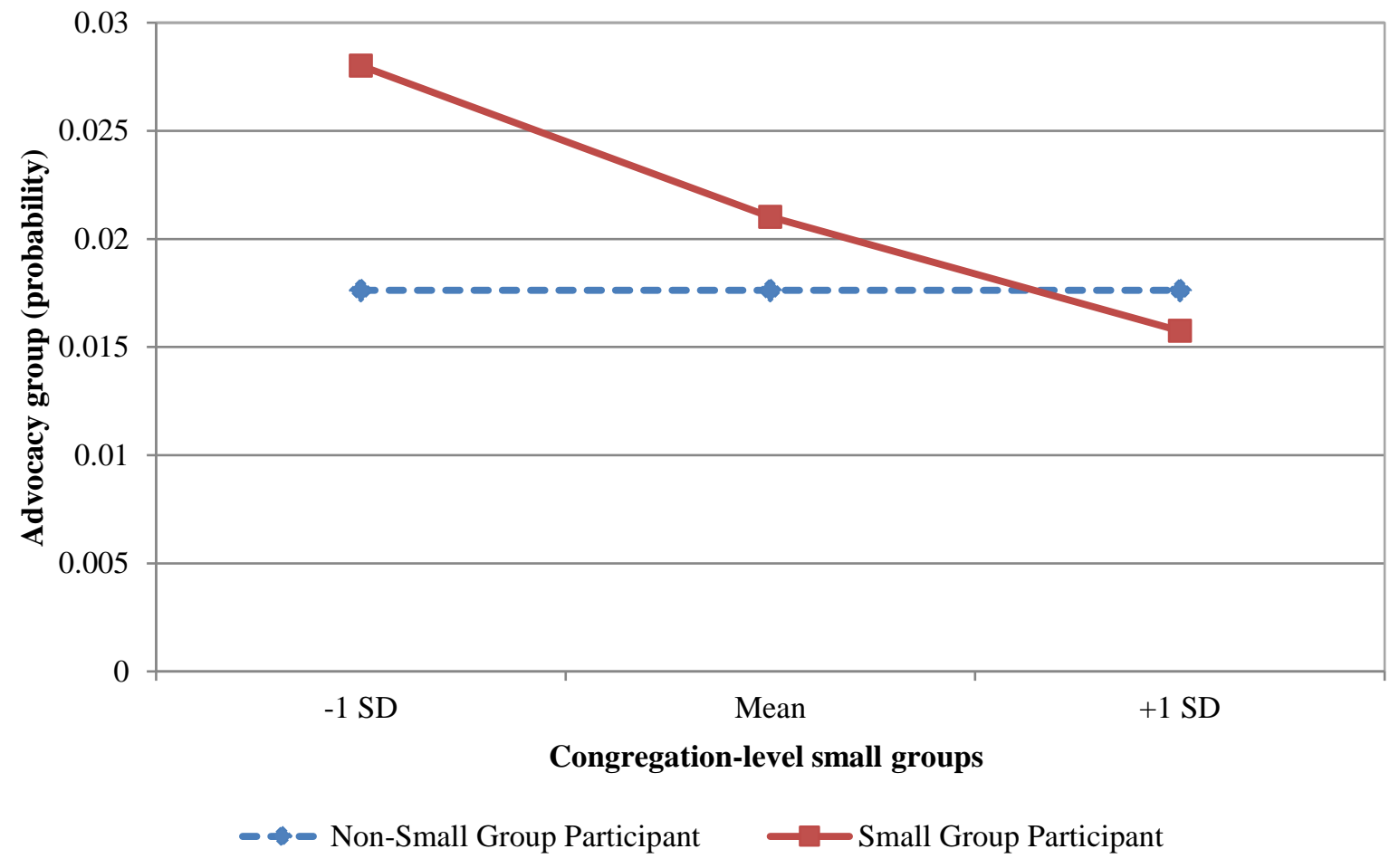

